Journal of Humanities, Social and Management Sciences (JHSMS)

eISSN: 2788-4791 (online)

https://doi.org/10.47264/idea.jhsms/2.2.8

Vol. 2, No. 2 (July-December 2021), 99-119

https://www.ideapublishers.org/index.php/jhsms

Research Article

\title{
Access to Justice: Comparative study of formal and informal dispute resolution mechanisms in district Swat, Pakistan
}

\author{
Irfan Ullah*1 $^{*}$ Muhammad Adeel Khan ${ }^{2-3}$
}

1. Department of Political Science, Faculty of Social Sciences, University of Peshawar, Pakistan.

2. Department of Governance \& Public Policy, Abasyn University, Peshawar Campus, Pakistan.

3. Department of Politics \& International Relations, International Islamic University, Islamabad, Pakistan.

*Corresponding Author Emails: irfandrs@uop.edu.pk

Received: August 10, 2021

Published: October 26, 2021

\begin{abstract}
Effective provision of justice remains essential for preventing wartime grievances into feuds and mass conflict in strengthening the state and improving accountability. It can lead to quick and cheaper resolution of disputes. This research focuses on evaluating the informal system of governance and justice delivery system in Swat, Khyber Pakhtunkhwa province of Pakistan. It evaluated the institutions of justice delivery (both formal and informal) in terms of structure, functions, and efficiency. The study reveals that informal mechanisms of dispute resolution is still preferred at large, despite the availability of formal institutions for this purpose. Majority of the respondents showed distrust on the formal institutions of justice delivery and dispute resolution across the sample population. This mistrust has been related to the ineffectiveness in terms of lengthy process of handling disputes of various types and the involved financial cost. Shariah and custom remained the preferred type of law to be adopted as compared to state law/statute for dispute resolution. The study concludes that state institutions of justice delivery and dispute resolution should work in collaboration with the informal institutions for effective provision of dispute resolution and justice delivery. A mixed method approach of depth interviews focus group and household survey is employed for collecting primary data.
\end{abstract}

Keywords: governance, justice, informal justice, formal justice, dispute resolution, alternative dispute, conflict resolution, jirga, police, courts.

How to Cite: Ullah, I. \& Khan, M. A. (2021). Access to Justice: Comparative study of formal and informal dispute resolution mechanisms in district Swat, Pakistan. Journal of Humanities, Social and Management Sciences (JHSMS), 2(2), 99-119. https://doi.org/10.47264/idea.jhsms/2.2.8

Publisher's Note: IDEA PUBLISHERS (IDEA Publications Group) stands neutral regarding jurisdictional claims in the published maps and institutional affiliations.

Copyright: $@ 2021$ The Author(s), published by IDEA PUBLISHERS (IDEA Publications Group).

Licensing: This is an Open Access article published under the Creative Commons AttributionNonCommercial 4.0 International License (http://creativecommons.org/licenses/by-nc/4.0/) 
Access to Justice: Comparative study of formal and informal dispute resolution mechanisms ...

\section{Introduction}

In post-conflict settings, wartime grievances linger and evolve into feuds, and legal institutions are particularly weak - reasons why most post-conflict countries revert to war and civil wars last there for so long (Collier, Hoeffler and Soderbom 2008). Effective provisions of justice play an essential role in preventing such grievances from evolving into mass conflict, in strengthening the state, and improving accountability. By providing effective provisions of access to justice to the people, it can lead to cheaper and quicker resolution of disputes and contribute to welfare of the poor and marginalized, who, otherwise, could have little power and resources to negotiate the customary justice system. Furthermore, they have little know-how of their legal rights and also, they are not in a position to bear the financial expenses of the formal justice system.

This study discusses and compares the functioning of different dispute resolution mechanisms in district Swat in the Northwest Pakistan. Through a combination of quantitative survey-based research with qualitative fieldwork on processes of conflict resolution, this research aims to describe and compare the functioning of these informal justice mechanisms in Northwest Pakistan as well as popular attitudes towards these institutions. This research surveyed the attitudes of people towards these institutions while also describing their functioning and the types of solutions reached. The research focuses not only on interpersonal disputes, but also the ways in which villagers deal with grievances about service provision of local governments. In doing so, this research aims to provide input for future interventions in this region.

This research focuses on evaluating the informal justice delivery system in Swat, Khyber Pakhtunkhwa province of Pakistan. ${ }^{1}$ In Swat, both armed conflict (2009-2012) and floods (2010) have created tremendous displacement and destroyed roads and bridges linking the remote mountainous parts of the district to market and urban centres. Experiences with armed conflict, natural disasters and the related instability have changed the socioeconomic landscape of villages by making already poor households increasingly vulnerable to shocks and forcing other households into poverty. The region is resident to the Pakhtuns, which is the biggest tribal society in the world (Spain, 1972, p. 117; Yousafzai \& Ali Gohar, 2005, p. 4) living in "a segmentary, replicating social system" in the North-West of Pakistan and Afghanistan (Barth, 1998, p. 117). Most of the literature on Pakhtuns, have described them as 'martial race' (Spain, 2009; Lindholm, 1982; Ahmad, 1980), a term contested in modern times by most of the Pakhtuns. Pakhtuns live their daily lives following the tenets of Pukhtunwali, an 'unwritten code' also called 'the way of Pakhtuns', 'the Pakhtuns code of honour', which regulates their lives (Sana, 2011; Spain, 2009; Sultan-i-Rome, 2009; Spain, 1985) in time of peace as well as war. Barth (1998) described features like 'egality", 'male autonomy', self-expression and aggressiveness some of the 'value orientation' of Pukhtunwali (Barth, 1998, p. 120).

Some of the major features of Pashtun society and culture are melmastya (hospitality), tarburwali (agnatic rivalry), Jirga (elderly council), nang (honor), hujra (male guest house), badal (exchange and retribution), riwaj (custom), parda (segregation of men and women), and Shariat (Islamic Law) (Taizi, 2007; Spain, 2009; Rome, 2008; Yousafzai \& Ali Gohar, 2005; Barth, 1998; Spain, 1985). Jirga is the centuries old institution of Pakhtuns' tradition, with accomplished capability for dispute settlement practiced by the Pakhtuns of Pakistan and Afghanistan. Jirga used to be the sole mechanism for state regulated administration of justice in the tribal areas (now newly merged districts) operated under FCR ${ }^{2}$ (Yousfzai \& Ali Gohar, 
2005; Mahmood et al., 2018; Alam et al., 2020). In certain societies, despite the established state institutions, community-based approaches are adopted by the local practitioners for bringing peace and stability in their respective communities. ${ }^{3}$ This (community-based) approach is considered more effective that the state institutions (courts in particular) ${ }^{4}$. State institutions adopt very lengthy and cumbersome process for dispute resolution, which a common person cannot afford. These informal/local institutions are mostly undocumented and not properly researched despite being well known in their communities ${ }^{5}$ (Spain, 1985; Sultani-Rome, 2009). Jirga being a traditional instrument of dispute settlement in Pakhtuns' society, provides informal justice delivery facilities to the people as compared to state institutions. ${ }^{6}$ It is regarded as a trusted and an effective instrument for dispute settlement in Pakhtuns' society (Taizi, 2007; Wardak, 2003; Yousfzai \& Gohar, 2005).

Taizi (2007) defined Jirga as a consultative forum or assembly where the relevant stakeholders/parties gather for consultation and to discuss all the issues related to dispute resolution. It is considered as vital judicial institution of Pukhtunwali and play role a judicial institution in Pakhtun society. Jirga usually consists of two or more person, depends on the nature of the issue involved. The members are normally family elders or their nominated persons who act as their representatives whose "Authority" and "competence" depends on the kind of issue the jirga has to deal with. Jirga perform roles, both of judicial and executive nature in disputes pertaining to land, feuds, blood money and other issues taking into account local traditions and principles of justice (Taizi, 2007, p. 2; Azim et al., 2018).

\section{Rule of law engagement with customary justice}

In conflict societies, scope of the rule of law reform is now being expanded in order to engage informal/customary justice systems that are time tested and are considered indispensable for justice delivery besides the state regulated $\operatorname{setup}^{7}$ (Kotter et al., 2015; Ahmad \& Wangenheim, 2021). But notwithstanding this recognition of the contribution of customary institutions, such engagement exhibits similar prejudices which are integral part of the state regaled system of rule of law. In other words, customary justice is recognized only when it operates in accordance with international rule of law and human rights standards. For instance, while the UN now realizes that informal justice systems are popular among majority populations in the developing world, pressure is being exerted on member states to ensure that these systems adhere to international procedural and substantive justice norms (UNDP et al. 2011). In terms of procedure, their settlement methods must be consistent with due process and objective rules that ensure certainty, accountability, and equality.

Normatively, informal mechanisms must respect and protect the basic rights of vulnerable groups as opposed to stipulating the rules by which those rights and duties are established" (Kerrigan, 2012, p. 11). To this end, the UN Human Rights Commission (UNHRC) requires that every state to protect women's rights including equality before the law and all rights related to contracts against the customary, religious or cultural practices used as a justification for violating these rights such as those enshrined in the CEDAW ${ }^{8}$. Emphasising these human rights safeguards is based on sometimes well-founded concerns that customary mechanisms in wartorn societies may have been coerced by powerful local elites, involved inhumane treatments of offenders, and are ill- equipped to handle criminal cases and inter-communal disputes, and generally discriminatory towards women and youth (Richards, 1996; Kerrigan, 2012; Pulver, 2011; Wojkowska, 2006). 
Access to Justice: Comparative study of formal and informal dispute resolution mechanisms ...

At the same time, an emerging critical rule of law argument has drawn attention to persistent technocratic, normative, and state-centric predilections in current customary justice reform interventions (Harper, 2011a; Isser, 2011; Kotter et al., 2015). This scholarship draws attention to the dangers of engaging customary justice systems in the same technical, legal, and apolitical fashion as their formal state counterpart. From an institutional perspective, the focus has been on state failure and the potential of a justice vacuum where regulation of customary systems is unaccompanied by the necessary state capacity to deliver satisfactory justice. ${ }^{9}$ The main thrust of the state-failure argument is that capacity deficit in formal justice system explains the popularity of informal justice mechanisms. Whereas the formal system continues to grapple with physical and economic inaccessibility, non-state mechanisms deliver relatively cheap, accessible, and expeditious settlement of disputes (Harper, 2011; Wojkowska, 2006). In terms of the political implications of institutional change, some authors have argued that rule of law reform would be confronted by resistance from non-state authorities who perceive such moves as threat to their political power and interests (Sriram et al., 2011).

A major shortcoming with this capacity-centred argument though is its inability to explain the survival of customary institutions where the formal state justice system has been capacitated and relatively functional compared to non-state institutions. The narrow focus on (in) effective state capacity limits understanding of situations where formal and informal institutional interaction leads to reciprocal reinforcement. Additionally, such an account assumes that informal institutions are endogenous to state failure-i.e., they emerged as a result of weaknesses in the state system. However, as discussed, unofficial customary justice systems predated even the colonial state building project (Englebert, 2000), and have survived postcolonial modernization and post-conflict state reconstruction (Isser, 2011; Logan, 2010).

Culture-based explanations attribute the popular legitimacy of traditional justice systems to their ability to resolve disputes in ways that are culturally relevant, acceptable, and familiar (Huyes \& Salter, 2008; Obarrio, 2011). From this perspective, the prevalence of customary institutions is construed in terms of specific characteristics and the type of justice they deliver in contrast to the modern state legal system. Here, the state system is juxtaposed with "informal justice processes capable of addressing cultural beliefs, norms, and practices that state courts or legislations ignore" (Kerrigan, 2012, p. 75). Emphasizing their intrinsic restorative attributes, traditional mechanisms are depicted in this literature as the appropriate medium to deal with private communal disputes such as witchcraft and sorcery, behaviour around sacred places, marital norms, and supernatural beliefs of acceptable behaviour. Culture-oriented arguments view local justice norms as intersubjective properties of a complex social unit which constrain individual preferences and therefore doubt whether imposition of international standards would achieve the expected change in beliefs and attitudes. When taken to the extreme, such arguments postulate that formal state justice systems would hardly become the forum of choice for the majority population in non-Western societies even if those systems were to deliver justice as effectively and efficiently as intended (Isser, 2009).

Although culture-based analysis is capable of complementing institutional arguments by underscoring the salience of nonmaterial values and identity, this line of thought tends to be essentialist with the tendency of gross overgeneralization about non-Western culture. In particular, essentialist claims portray culture as deterministic or at least semi-primordial, deeply rooted in history, religion, ethnicity, and social organization. The resilience of customary justice institutions is explained in terms of their embeddedness in local customary practices 
linked to particular familial, ethnic, or clan-based affinities. Apart from cultural reductionism, such portrayal of culture risks being an orientalist, which Edward describes as the propensity of the Western scholarship to depict non-Western societies as the alien, ahistorical, and unchanging "other." It was from this stereotypical depiction of non-Western culture that Abel links institutions and patterns of disputing in pre-capitalist societies exclusively to their social structure, defined as one in which relationships are multiplex, fundamentally undifferentiated, affective, and enduring.

These explanations are not mutually exclusive, and both do not entirely challenge the view that formal state oversight and international principles should be used to eliminate discriminatory and arbitrary practices in customary justice systems. Some of these peace building authors write from an international relations background that privileges the nation- state while others are trained in human rights law. Those who make institutional arguments are critical of the rule of law orthodoxy only to the extent of drawing attention to the effects of premature formal regulation (Baker, 2009). In interrogating universalistic claims, these authors seek to provincialize the normative origins of international rule of law in Western liberal democracies in order to make a case for an approach that is more sensitive to local contexts. Culture-based contention is not about challenging claims that customary practices such as trial-by-ordeal violate fundamental human rights but rather that supernatural problems such as witchcraft are prevalent in non-Western societies and legal- rational institutions are by their very design illdisposed to handle those matters (Isser, 2011). In other words, inasmuch as customary conflict resolution contravenes human rights standards, those methods must be appreciated for maintaining order in a realm beyond the competence of modern formal states-i.e., the irrational, illiberal, emotional, and spiritual arena.

Despite progress in demystifying customary justice practices, no attempt has been made to systematically theorize the interplay between justice norms, institutions, and the local political economy in war-torn societies. An exception is Baker's network analysis of nexuses between state and non-state justice and security systems in the areas of intelligence gathering, shared equipment and training, joint patrols and operations, and enrolment. Some policy research papers have also focused on functional and rule-based linkages between formal and informal justice systems (Wojkowska, 2007). Yet these analyses do not take into serious consideration questions relating to political authority and social relevance of institutions in non-Western societies. Traditional authorities are portrayed as justice and security providers by default of the state' inability to effectively or legitimately perform its functions, without fully appreciating their multiple sources of authority as well as the politics of customary institutions which the state itself may actively encourage or at least be complicit in perpetuating. These studies assume the usual liberal public-private distinction with a tendency to bifurcate between state-constituted and civil society-based institutions. Although it is acknowledged that these categories are mutually permeable, attempts to produce greater conceptual gradation based on micro-level variations within the nation-state are rare (Sinha, 2012; Ahmad et al, 2017). Analytically, there is paucity of understanding of diverse interplay between the rule of law and societal forces to tease out multiple effects. ${ }^{10}$ It is not clear how the interaction of justice norms correlates with regional socio-economic development disparities, local authority structure, and connections between local and national elites in post conflict societies.

Methodologically, the literature on rule of law in war-torn societies remains largely trapped in state-centric analysis fixated on national-level indicators to study countries with high degree of 
internal heterogeneity. Although the bulk of this research are qualitative case studies drawing often from historical and anthropological data, many rely on what Snyder 2001 calls "meanspirited analysis" that "masks important differences in the distribution of traits as well as in the degree of dispersion of such traits". A standard practice is to incorporate quantitative analysis to express in numeric terms national aggregate usages of customary justice mechanisms in contrast to the formal state system (Isser, 2011; Wojkowska, 2006). Where attempt is made to go beyond numerical measurements to understanding particular customary practices, there is also the problem of "invalid part-to-whole" mapping. What this means is that "attributes specific to a well-studied area or especially salient unit are improperly elevated to the status of a national paradigm" (Snyder, 2001). Here, the literature would highlight certain ritualistic practices or mechanisms which are specific to a locality as if the whole nation possessed them or as if such attributes constitute customary justice systems as a whole. Apart from neglecting day- to-day common sense approaches, an almost exclusive focus on the well-known caricatures often ends up either castigating entire customary systems as irredeemably illiberal or romanticizing certain cultural attributes. ${ }^{11}$

What accounts for these omissions is the lack of dialogue between international relations and comparative politics to combine macro-national perspectives with subnational variations to understand complicated political outcomes? For example, the literature on customary justice in war-torn societies is completely bereft of broader discussions about the institution of chieftaincy and politics of informalization even though these processes are central to the resilience of customary institutions in heterogeneous non-Western societies. This research helps to bridge this gap in the literature in order to enhance deeper understanding of the rule of law engagement with customary justice systems in conflict societies.

\section{Methodology}

This research study is conducted in district Swat of Khyber Pakhtunkhwa Province, Pakistan, using primary data, gathered through key informants' interviews and household survey on informal justice system. A mix-method approach has been employed in order explore the proposed research questions. The data is collected through a combination of a quantitative survey and ethnographic fieldwork. A general survey among both common villagers and informal justice providers (JP's) was conducted in the selected districts to assess both legal needs as well as attitudes towards, and experiences with, formal and informal dispute resolution. In each village, both men and women (both randomly selected) were interviewed, together with informal justice providers (hereafter JPs) ${ }^{12}$.

\section{Formal dispute resolution: Police and Courts}

It discusses prevalent attitudes towards the formal legal system (police and courts) in Swat. After a brief survey of common disputes and grievances, we discuss the levels of legal awareness among the population and the aversion to the involvement of police and courts to address disputes, in Swat district.

\subsection{Types of disputes}

Out of the households surveyed, almost twenty percent of respondents reported involvement in a dispute. This percentage involves both interpersonal disputes as well as disputes with 
government institutions, to be discussed below. This is a relatively high percentage, more so given the fact that sensitivities over conflict might lead to underreporting. Levels of conflict seem particularly high, where number of interviewed households reported involvement in a dispute. Figure 1 provides an overview of the types of conflict most commonly experienced. A number of things stand out. Firstly, conflicts over employment (i.e., mostly wages) and land are the most common disputes between individuals, while informants also face recurring problems in obtaining civil documents of government agents. Land conflicts are particularly common. Disputes over land vary from confiscation of land in the absence of the owner, to relatively small issues like someone's livestock running over someone else's land. As the population is growing and land gets fragmented (through division between heirs) more and more disputes are arising between close heirs of a common ancestor. The high number of murder cases in swat is also notable.

Figure 1: Type of dispute

\section{Type of Dispute}

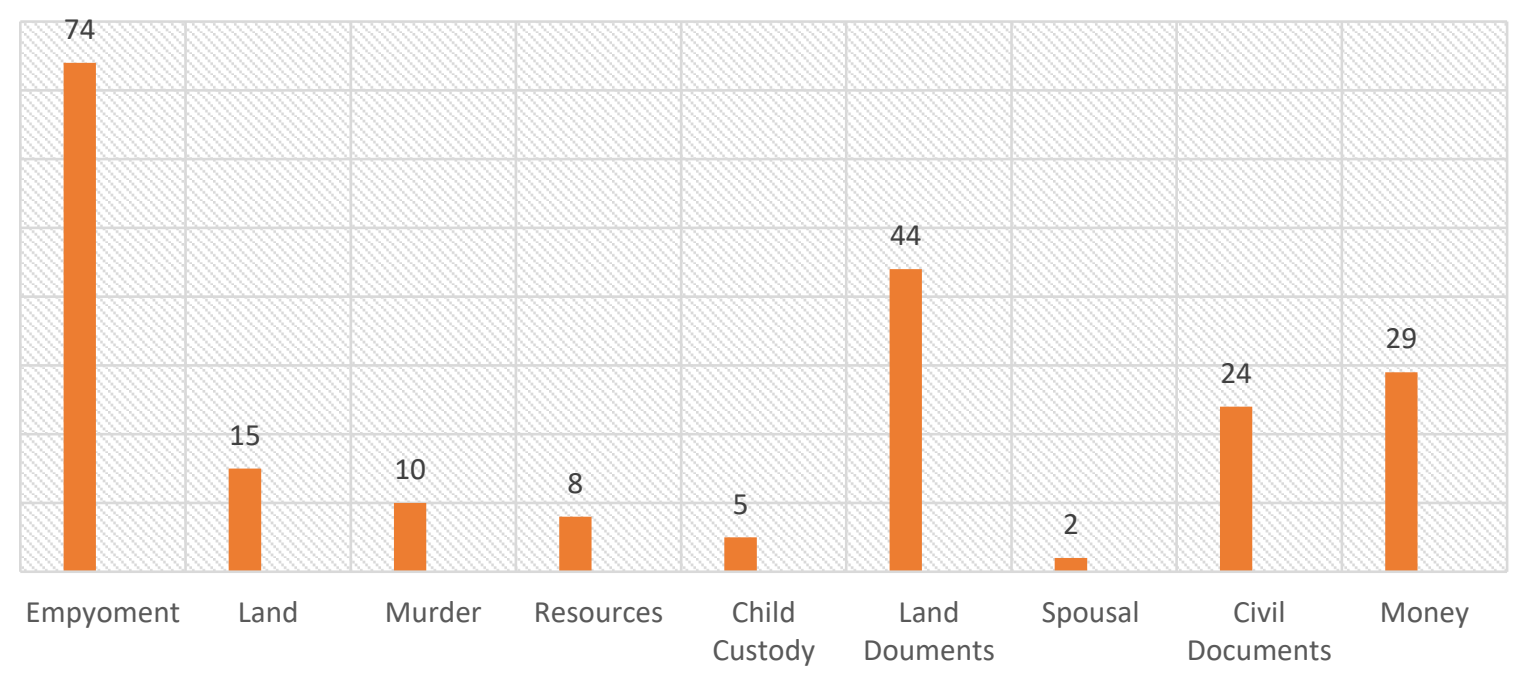

Figure 2: Information source regarding justice forums

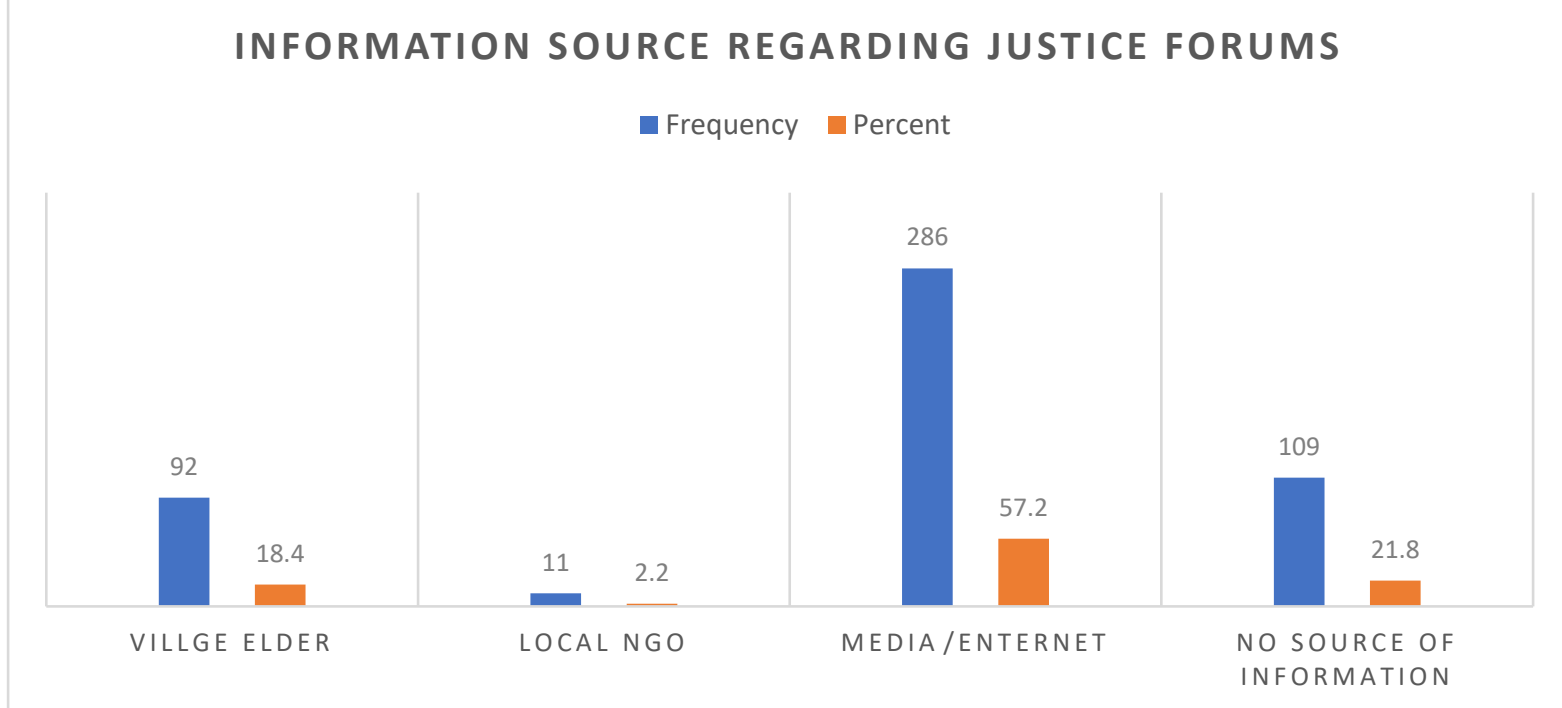


Access to Justice: Comparative study of formal and informal dispute resolution mechanisms ...

\subsection{Involvement of the Police}

The tables below report the level of trust towards the police and the courts, for women (f), men (m) and justice providers (JPs). These gendered results suggest a keen awareness of women that the male dominated nature of customary institutions puts them at a disadvantage - leading to a slight preference for the comparatively slower formal legal system.

Figure 3: Confidence level in Police

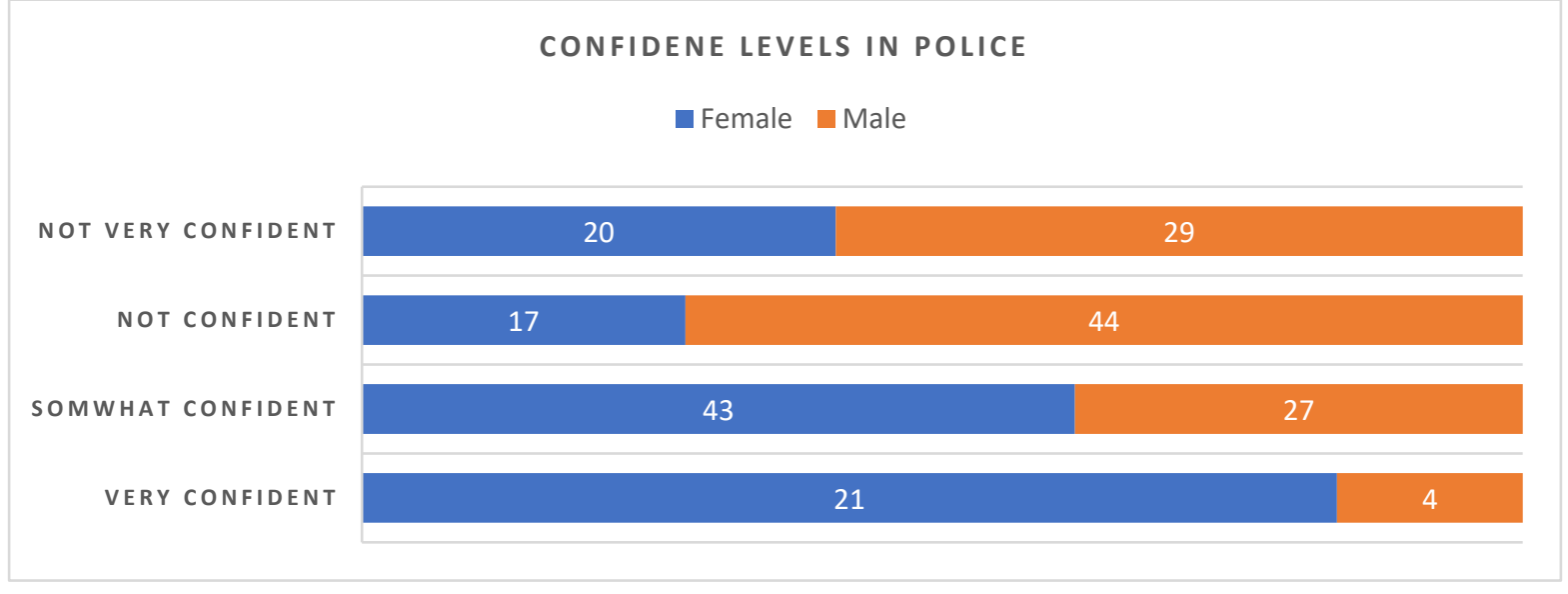

Figure 4: JP's confidence level in Police

JP CONFIDENCE LEVELS IN POLICE

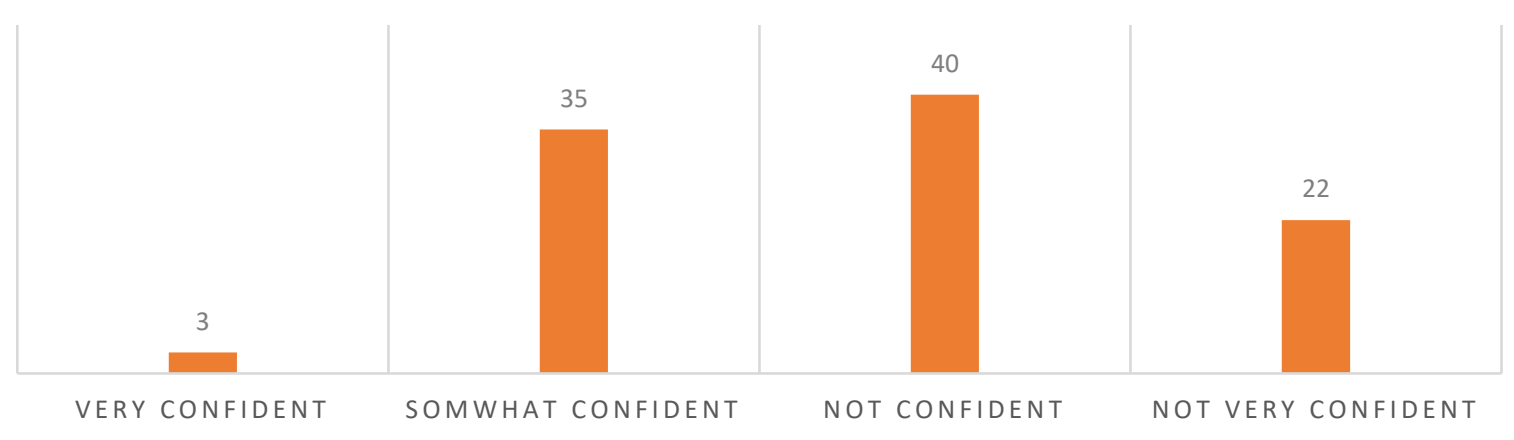

Figure 5: Percentage of respondent types reporting various confidence levels in Jirgas

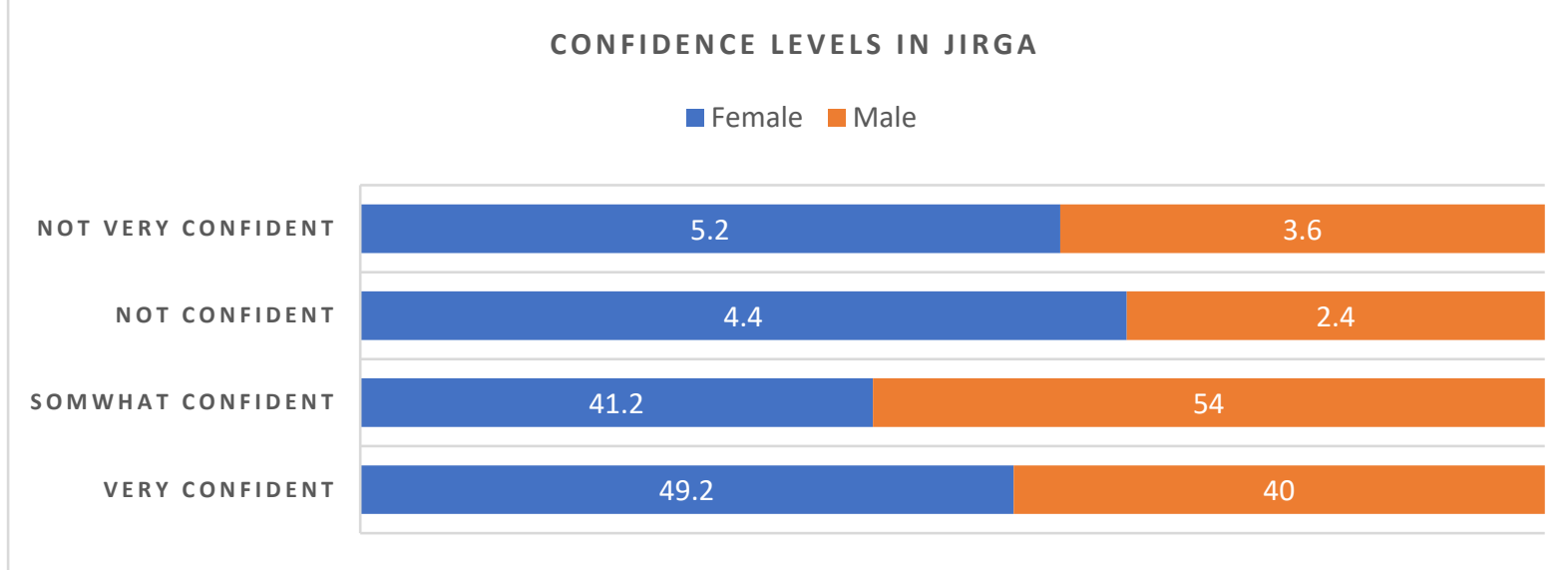


Jirga system is very effective in dispute resolution as compared to police. The reason is that police usually take too much time in solving a case and the fees of lawyer are quite high, while Jirga solves a dispute in few days and free of cost. According to the people, Jirga solved almost all type of cases like Family disputes, individual disputes, Murder cases etc., and the decision making of the Jirga Masharān is fair and based on Justice (Interview, 2017)

Figure 6: JP's Confidence level in Jirga

\section{JP CONFIDENCE LEVELS IN JIRGA}

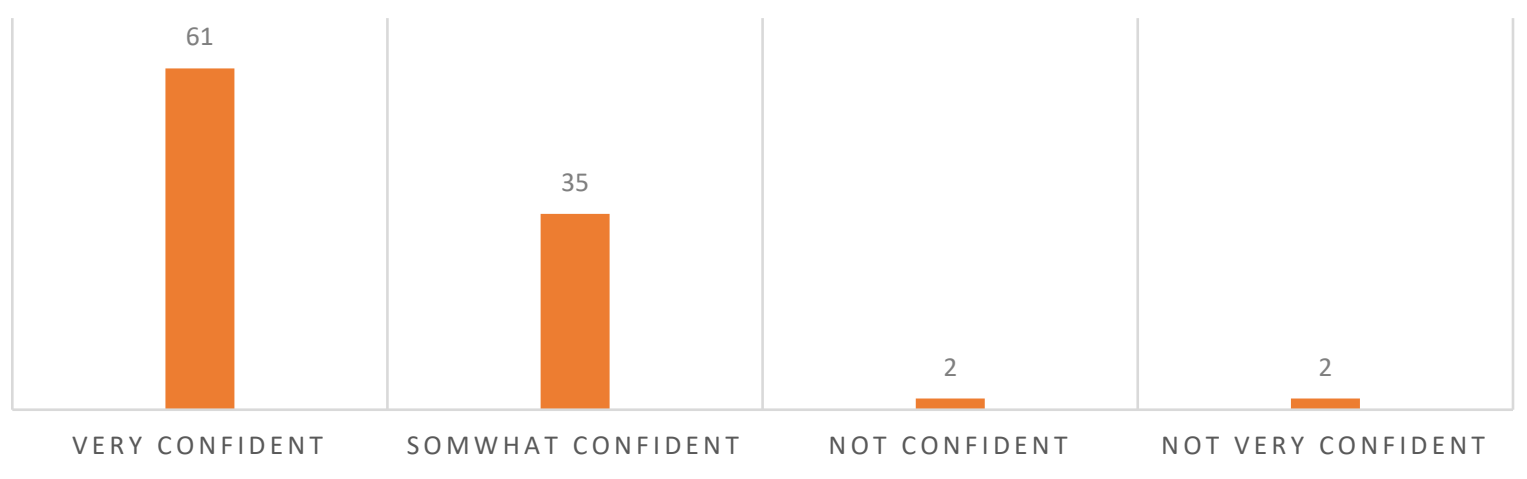

Figure 7: Respondents' confidence level in Local Courts

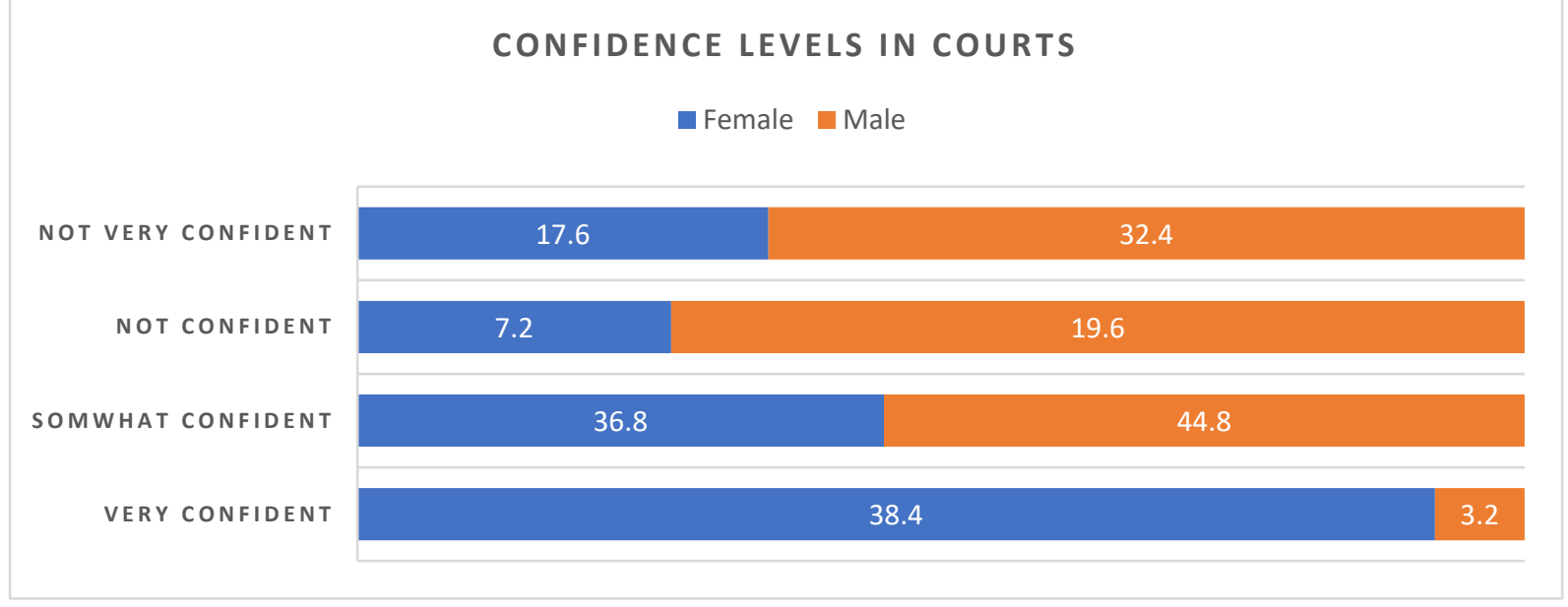

Figure 8: JPs' confidence level in Local Courts

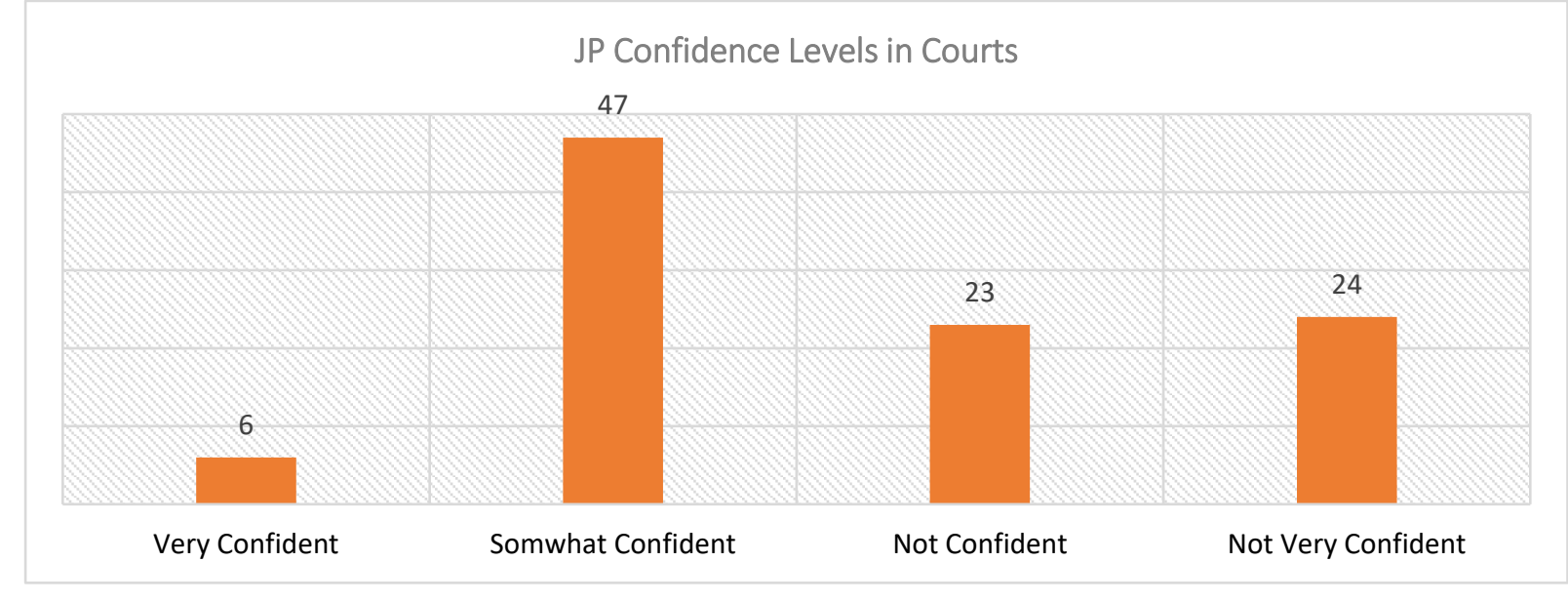


Figure 9: Respondents' confidence level in committees

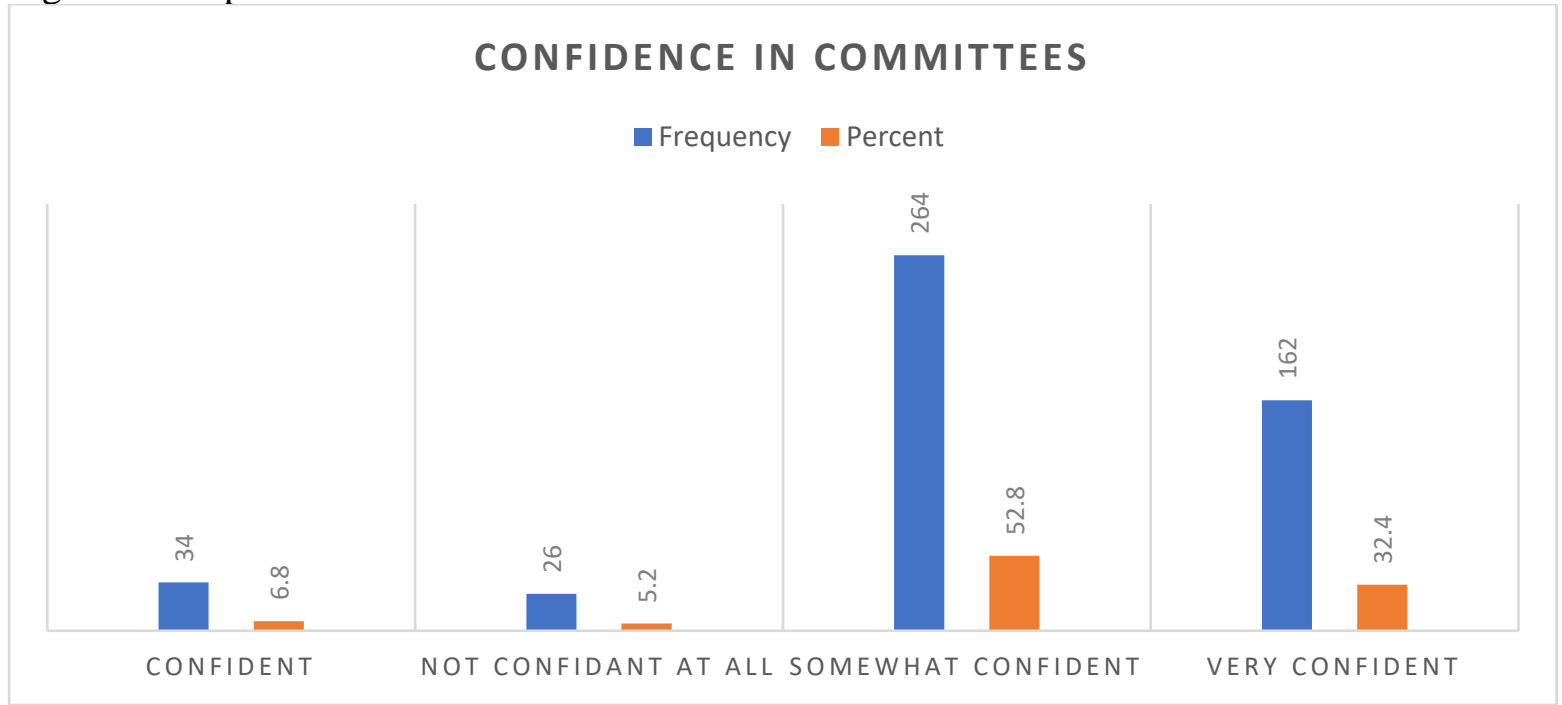

These results are mirrored by the levels of legal awareness found in district swat. Participant observation corroborates these findings. Interaction with the police is rarely pleasant. When people go to register an FIR, for example, the police, first, does not even listen to the complainant until the social background and status of the complainant is verified. Secondly, if the complaint is against a wealthier and/or a well-connected person (e.g., a Khan or a Malik etc.), the police official in charge would be inclined to ask his superior if a case is to be registered or not. Furthermore, there is a general lack of trust between the community and the police due to various forms of rent-seeking by police officials. Not infrequently, these officials use their office to take bribes both in kind and in cash, for taking up false cases against rivals. The police on the other hand blame the political elite for anything wrong they are involved in. "I swear in the name of God that we are forced to do wrong things by the political people, we are helpless" said a police officer in Swat. "Police personnel sometimes have to work 24 hours shifts; how can you then expect a policeman to be friendly with someone who comes to the police station when he has just finished off 20 hours of his duty?" said another police officer in an informal conversation in Swat.

Similarly, the courts are distrusted and, due to big backlogs, procedures take a long time. Many of the people interviewed are of the view that courts' decisions are manipulated by powerful lawyers in most cases. Lawyers are considered to have become important players in recent years, capable of influencing administrative and other decisions outside of the courts. Furthermore, the obstacles in bringing a case to court are considerable. After successfully registering a case with the police, various procedures need to be navigated to get a case heard at the court. These procedures are, for most people, intimidating and opaque, and the unpleasantness can be compounded by harassment (by officials and the other side), demands for bribes and the perception that court clerks pay less attention to poorer segments of the community. There are thus good reasons to avoid the formal legal system altogether. This is reflected in the low levels of trust in the police and courts.

\section{Outcomes: Police and Courts as pressurizing instrument}

A recurring element of the cases studied for this report that went to court, was that although 
the court cases were withdrawn before reaching a verdict, the court case itself served to pressurize disputants to reach an agreement. Consider the following cases:

\section{A. Case Study: 01}

A murder case was initially reported to police and then court. It stayed unresolved in the court for two years until it came back to the Jirga which decided the case on the basis of the principle of diyat. Diyat is an [Islamic] Sharia principle according to which, based on the consent of the family of the one killed, the family can be compensated with money or anything equivalent in kind. The substitute is Qisas, capital punishment, i.e., a head for a head. The Jirga ordered that the family of the victim be compensated with 2 million Pakistani Rupees (about 20 thousand dollar). The Jirga Masharan (elders) proactively engaged in this dispute. As they considered the court to have failed to resolve the dispute, they approached the accused's family and the other party to come together for conciliation.

\section{B. Case Study: 02}

Jalal was constructing the street. The total width of the street was about 8 feet. Ghafoor asked Jalal to increase the width and construct the street till the end. The house of Ghafoor was located at the dead end of that street. His aim was to make the street wide so that he can take his car to his house. While Jalal, who was constructing the street, said to him that he can't increase the width because the land belongs to some other people. But Ghafoor said that it is a government road, and no one can stop it. They were living in the same mohallah. Both the parties showed aggression and fought with each other. Some people got injured during the fight. This was the period of Taliban in Madyan. The police were not registering FIR. They approached police but the police didn't registered FIR. The issue continued for some time. Some people also tried to settle the issue between them but failed. Then both the parties went to the court and started legal proceedings in the court. During this period a person intervened between the two parties to resolve their issue. He got succeeded in resolving the dispute. "He was sincere in his effort to resolve the dispute between these families. The main thing which is very important in resolving any dispute is sincerity on the part of jirga masharān. Dispute can't be resolved without sincerity on the part of masharān". jirga decided that the width of the street will remain the same. The decision of jirga has been written on a stamp paper and presented in the court as an agreement deed (razinama). The case was withdrawn from the court by the parties, and they pledged to live happily in future.

Both the cases also illustrate that sometimes there is uneasy coexistence of the formal and customary legal systems. The retributive nature of state justice often does not reverberate with local interpretations of justice, which can motivate Jirga elders to seek to find a compromise before a court verdict is reached. Their reason for engaging in murder cases is pragmatic. According to the formal law, which is based on Sharia principle, if the court establishes that the accused has committed the murder, there is a risk that he/she may receive a capital punishment which in turn leads to a continued rivalry between the two families. It is to mitigate such a risk that Masharān say they approach the family of the deceased asking them to withdraw the case and resolve it by accepting the monetary compensation, as has happened in the case mentioned above.

These examples illustrate how the formal legal system often relies on informal mechanisms. 
Access to Justice: Comparative study of formal and informal dispute resolution mechanisms ...

Even in cases where there is a legal requirement to process a case - such as murder - police officials generally are very open to drop a case once a compromise have been reached through informal mediation. Even the police regularly refer civil disputes and minor criminal cases to an informal institution. For example, in cases of theft the police would often refer the case to the elders of the village or quietly call-in family members to resolve the issue in secrecy through a compensatory payment. The police and lawyers venerate such informal work they perform, and they call it a 'public service', or 'service to humanity' (khidmat-e-khalq). This preference for such informal settlements illustrates a widespread hesitance towards the kinds of retributive punishments prescribed by state law and a preference for restorative justice.

In Swat, this preference for restorative justice provided by Jirgas extends to murder cases. Jirgas have for a long time settled such cases; Pukhtunwali prescribes various forms of punishments for murder - such as 'badal' (a sanctioned revenge killing), 'swara' (giving away a girl in marriage) or 'paighor' (a family humiliation in front of a large group during a Jirga). It should be noted, however, that this only happens when the family wants to resolve the issue through conciliation. But even when taken to the informal system, the formal justice system plays an important, if unplanned, role: even if many disputes thus end up being settled by informal mechanisms, disputants still often opt to report the case to the police in order to improve their bargaining position. The filing of an FIR, it is believed, would intimidate the other party. The underlying reason for the fear is that statutory laws proscribe capital punishment for murder. This threat can be used to pressurize the perpetrator to settle the issue by paying a fair amount as a compensation. In such cases, the people prefer police (pa dasi masalo ki khalak awal police la zee). Some people tried to resolve the case, but they could not succeed. The case was taken to the court by both parties in order to identify the boundary of the street's property.

\subsection{The shadow of the law}

There is a general aversion to involve formal legal system due to its costliness, slowness and corruptibility. The content of the laws and particularly the retributive nature of its prescribed punishments, often clashes with local perceptions of justice. Yet even if many cases end up being mediated through informal mechanisms, state law is hardly irrelevant. As the above discussion about murder cases illustrated, what matters in many cases is not the law itself but the shadow of the law, i.e., the interpretation of what the law in the particular case is, and what might happen if the case would go through the formal system. Dispute resolution in Northwest Pakistan is shaped by the interplay between state and customary rule systems, as both disputants as well as justice providers involve considerations of state law in informal dispute settlement. In terms of engagement with the state institutions to gain access to, or improve provision of public services, the presented picture is mixed: while respondents said they reported issues relatively often to state authorities (who are relatively well-known), civil society organizations are weak. The survey suggests that there are very regular complaints about the provision of state services. As local Jirgas seem to play a limited role in conveying these grievances to state officials, there seems to be a lack of organizations capable of aggregating interests and organising community mobilisation.

\subsection{Informal dispute resolution: Jirga}

Jirga is a mechanism through which Pashtuns in parts of Khyber Pakhtunkhwa, Balochistan 
and Afghanistan handle disputes (inter family, intra-family, inter tribe, intra tribe and regional disputes). One of the interviewees shared:

"When some trusted elders in a village, ranging from 3 to 20 gathers in a village and resolve disputes of the people, it is called jirga. In almost every issue, elders get assembled and resolve that issue very easily through jirga" (Interview, 2017).

"Those persons in society who are impartial, knowledgeable, have patience, having status in society and age also matters. When such persons, from mohallah and village gathered, it is called jirga" (Interview, 2017).

Though complex in terms of composition and processes, Jirgas have been and continue to be pivotal to conflict management/resolution in Pashtun society irrespective of whether they make 'just' decisions or not. Jirga can be defined as "Building unity and cohesiveness and having broad consensus on different issues. It is not mandatory Jirga to be a formal body. Normally elders are considered to be part of Jirga but there is no clear job specification. Age is one of the important factors, but it is not the decisive factor for becoming a Jirga member, beside age, family status, income, Land ownership and social ownerships does contribute a lot to the membership of Jirga.

"Those jirgas are successful, which includes some influential and respected personalities as jirga masharān, because when some influential and respected person visits one's door in jirga, he cannot refuse him" (Interview, 2017).

Moreover, the succession plan is dynastic by nature. There are no formal places to conduct the Jirga. Normally, Hujras are used for its meetings and for more sensitive cases of disputes, mosque are also used, reason being is to enforce the Jirga decision in a holy place and in the name of God, other reason for using Mosque for conducting Jirga is that Hujras are small for conducting a Jirga and it is difficult to accommodate all the members of Jirga in a small Hujra, therefore it is preferred to use mosque rather than Hujra for conducting a Jirga. Also, religion brings together differences.

Another important aspect is to enforce the decision of Jirga through collateral. Normally weapons are accounted in terms of collateral. But use of collateral varies from village to village. Some of the Jirga masharān consider the use of collateral in Jirga a wrong act. According to them the collateral evokes the evil thoughts of the justice provider (zamanat rakhne se logon ki niyat kharab ho jatihai), and because of this collateral, the Jirga Masharān takes decisions based on their own self interests. Before the start of Jirga, the two opposing parties put forward their cases to the respective arbitrators which the villagers called "Mukhtar" or Jirga Masharān, and then these arbitrators make their decisions based on witnesses produced and evidence provided. The Jirga will not be started unless both the opposing parties select a "Mukhtar" for themselves.

It has been observed that Jirga has different level of forms. The common daily life disputes or family disputes are solved by the common people of the community, but if the dispute is sensitive then it is usually discussed by the prominent villagers or Jirga masharans. It has also been observed that it also depends on the social contacts of the complainer that which level of 
Access to Justice: Comparative study of formal and informal dispute resolution mechanisms ...

Jirga he/she can approach. The other type of Jirga which I have found is the Ijtimai Jirga, this Jirga is constituted for resolving disputes between different tribes or Khels. People from different Khels in different villages participate in this type of Jirga.

The Masalihati committees have been established at police stations level in the respective area. According to common people this committee is political in nature and is not effective in dispute resolution, and most of the members of the Masalihati committee consists of the people of political parties or ex-Nazims. One of the respondents commented:

"The government is supporting the Masalihati committees, but we don't have any support from the government and the police" (Interview, 2017).

During wāli-e-swat reign, he used to nominate maliks in every village. They used to resolve disputes of the people. Maliki system is no more functional, but maliks still have respect in society and people still bring cases for resolution. They are usually wealthy and have land tracks, which add to their influence in society. Previously they took $10 \%$ share of the fine, if imposed on any of the disputants. This was fixed by wāli-e-swat as remuneration for them (Interview, 2017).

"In Jirga system normally, justice is being done on the principle of expediency, cost effectiveness and trustworthiness" (Interview, 2017).

It has been observed that the influential and prominent local elders are regarded by the society in large and assigned decision making role in local Jirga system is because of their land ownership and strong social capital. Jirga proceedings are conducted in a secrete way. "Jirga proceeding, in some cases are open. In some cases, we keep secret from the parties and will use as a trump card when the situation demands" (Interview, 2017). Masharān, listen to one party's demands and then go to the other party, in order to inquire whether the demands made by one party are acceptable to the other or not. When both the parties agree, then the decision is announced.

"Jirga develop strategy that whether we should allow both the parties to sit together or not. Usually, jirga first approach one party and then the other. They do this till the situation is balanced (both parties agree on the terms to resolve the dispute)" (Interview, 2017).

"Most of the family disputes remain unresolved due to the inflexibility and less openness of the cultural norms especially in terms of family honour. But he says most of the people trust him and come to meet him to resolve their family conflicts" (Interview, 2017).

Cultural issues are normally not addressed in the court of law and local Masalihati Committee because of sense of humiliation to family in a public forum. Therefore, it is pivotal to enhance trust building and mutual respect for the eradication of these kinds of social evils. for conducting Jirga, you have to be brave enough. Court also seeks Jirga's suggestions in order to resolve the case. It usually happens in those cases where the Jirga unable to solve the cases (Interview, 2017). 


\subsection{Jurisdiction of Jirgas}

To study the scope of perceived jurisdiction of Jirga system, we put hypothetical cases to survey respondents and asked them to which forum they would take the issue. The results are similar to the pattern discussed above, as it reflects a markedly higher preference for the informal system.

"People usually prefer jirga, even if they approach police or the court decides their case, but the issue can't be settled until it is resolved through jirga" (Interview, 2017).

Another remarkable aspect of these survey results is that the type of issue/dispute does not really seem to shape the preference for either Jirga or formal local court: even in a criminal (murder) case, people display a marked preference for taking the issue to a Jirga. Yet the inheritance case showed a larger preference for the local courts, which is interesting: such issues used to be settled by Jirgas alone. The reported preference for the local courts might indicate that the way in which customary law decrees that such disputes should be solved Pukhtunwali is generally taken to imply that all inheritance should, generally, go to male siblings, no longer seems right for many ${ }^{13}$. This deserves further study and is something for a legal empowerment program to take up.

Interestingly, these results seem to contrast with the scope of jurisdiction that informal Justice Providers would consider themselves to have. They were asked what kind of cases they would take up. In Swat, where Jirgas are much more institutionalized and the interaction with the police is more regularized, Jirga members seem more likely to refer cases to the police. Figure shows percentage of JPs who would personally resolve the following types of disputes (Willingness to take on Disputes).

Figure 10: JP preference of dispute type to participate in their resolution

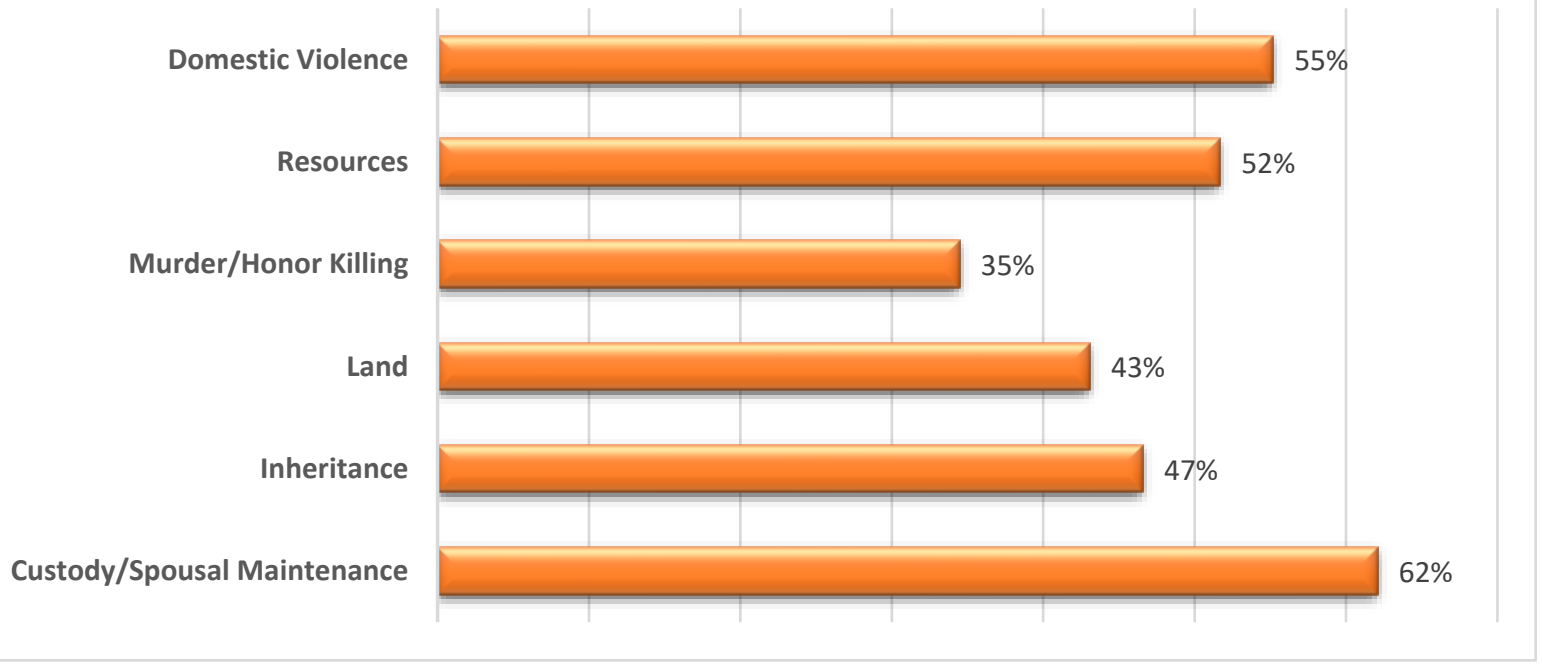

\subsection{Pukhtunwali and state laws}

In our survey, we asked what kind of rule, procedure and system the justice providers applied when deciding on a case. The results suggest that Shari'a law has been making great strides in 
the recent years. Yet this is probably partly due to self-presentation of justice providers: the current political atmosphere - i.e., the predominance of political Islam - proscribes such answers, while the actual outcomes of the disputes do not necessarily reflect sharia law (See, Khattak et al., 2017).

The customary norms (Pakhtunvali) are also regularly invoked as the basis for these verdicts or outcomes of the mediation practices. Nonetheless, Pakhtunwali is a set of norms that generally prioritizes restorative justice over retribution: the emphasis is on compensating the victim rather than punishing the perpetrator. As the state officials are often keen to pass on the cases to a Jirga, there is little monitoring of whether the subsequent verdict corresponds to the state law or not.

\subsection{Social inequalities and dispute resolution mechanisms}

A key characteristic of both formal and informal dispute resolution mechanisms is the large impact of social inequalities on their functioning and the solutions they provide. That constitutes a key challenge for access to justice: this needs to be guided by a keen sense of how different dimensions of social inequality - not just wealth, but also status, social capital and cultural capital play an important role - shape the process of seeking redress for an experienced injustice. It is important to assess both the varied nature of local social inequalities as well as the way in which they impinge on dispute resolution.

\subsection{Evaluations of formal and informal institutions}

The main requirement which is important in resolving any dispute is sincerity on the part of the jirga masharān. Dispute cannot be resolved without sincerity on the part of masharān because Trust, sincerity and impartiality are important in resolving disputes. People usually trust those jirga masharān, who decides cases based on honesty, truthfulness and justice (Interview, 2017).

Figure 11: JPs' Influence

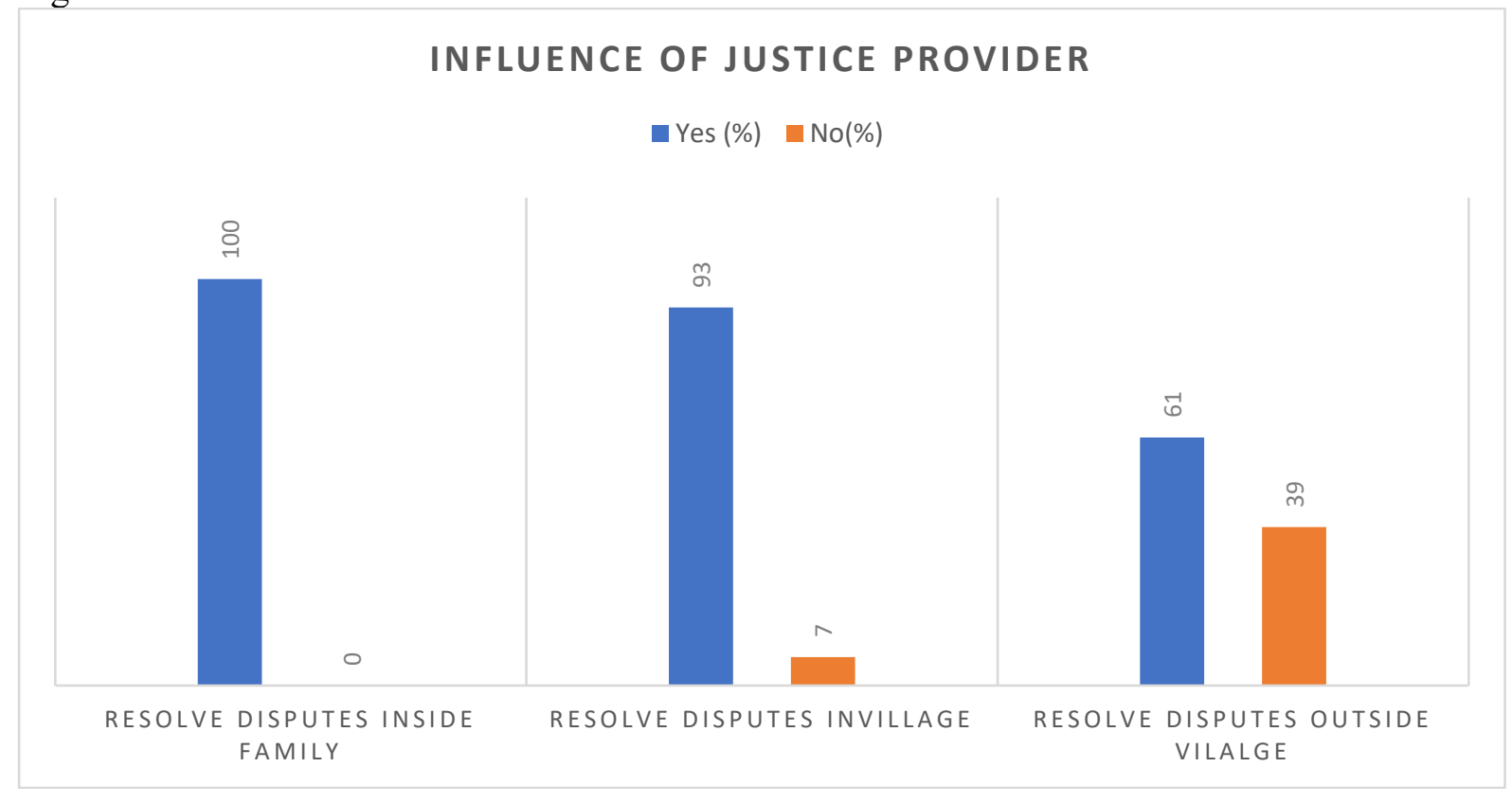


Figure 12: JPs' decision-making ability

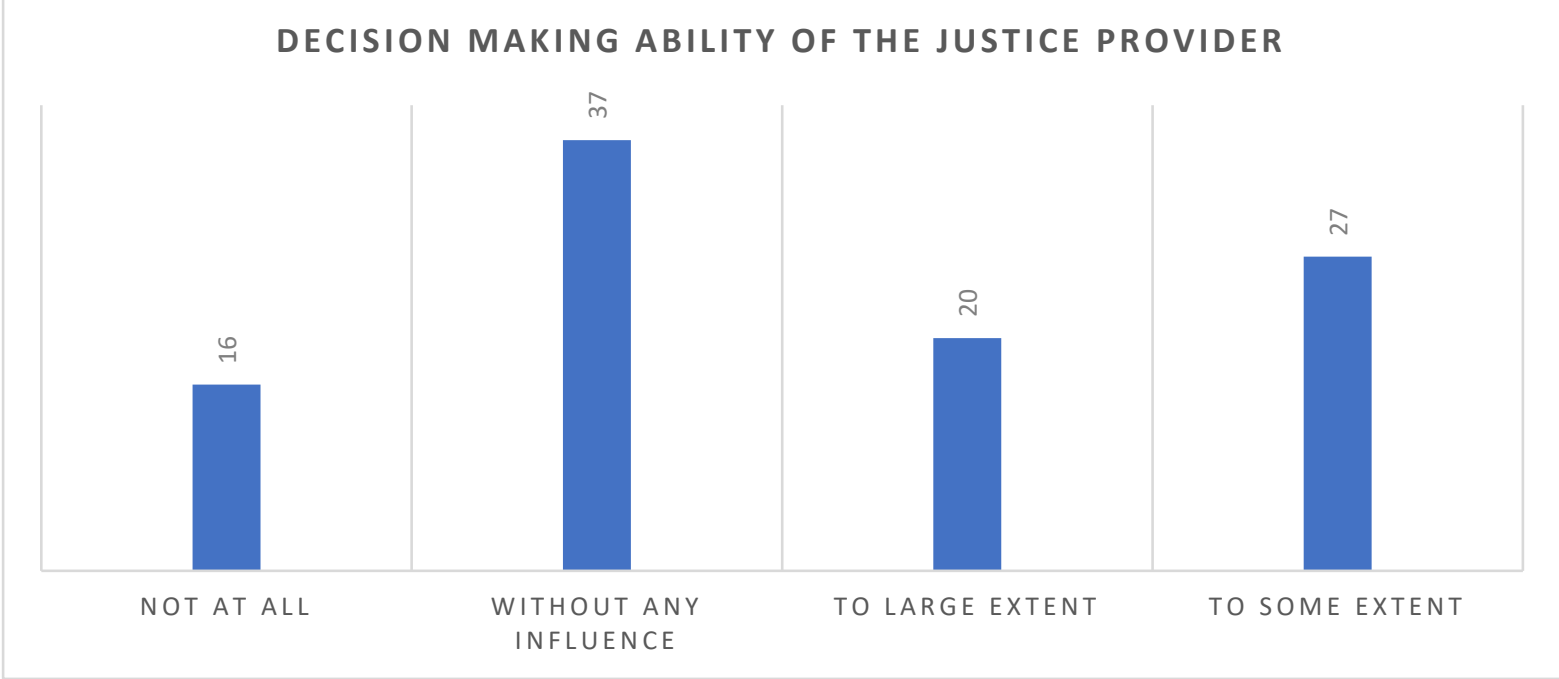

Figure 13: Respondent types reporting that they find Jirga fair/trustworthy, affordable and speedy

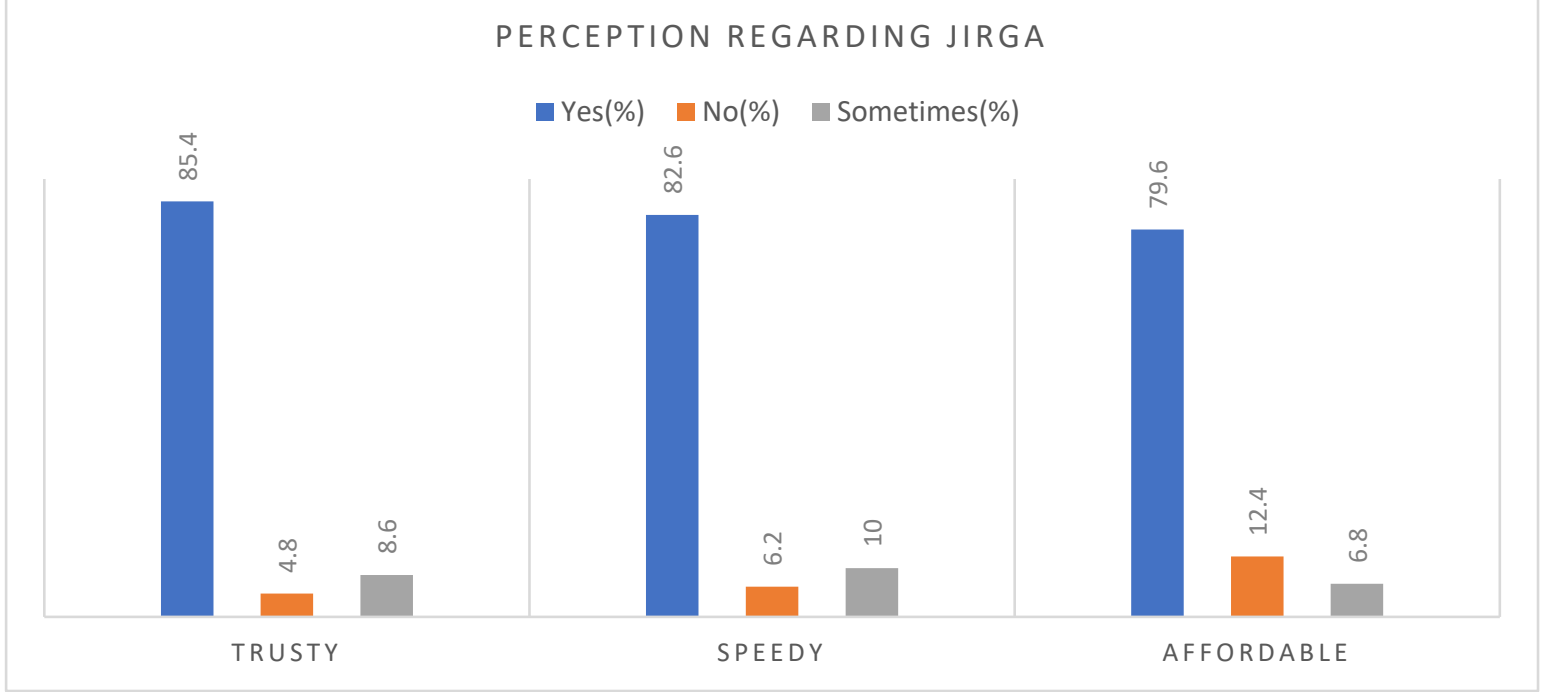

Figure 14: Respondent types reporting that they find courts fair/trustworthy, affordable and speedy

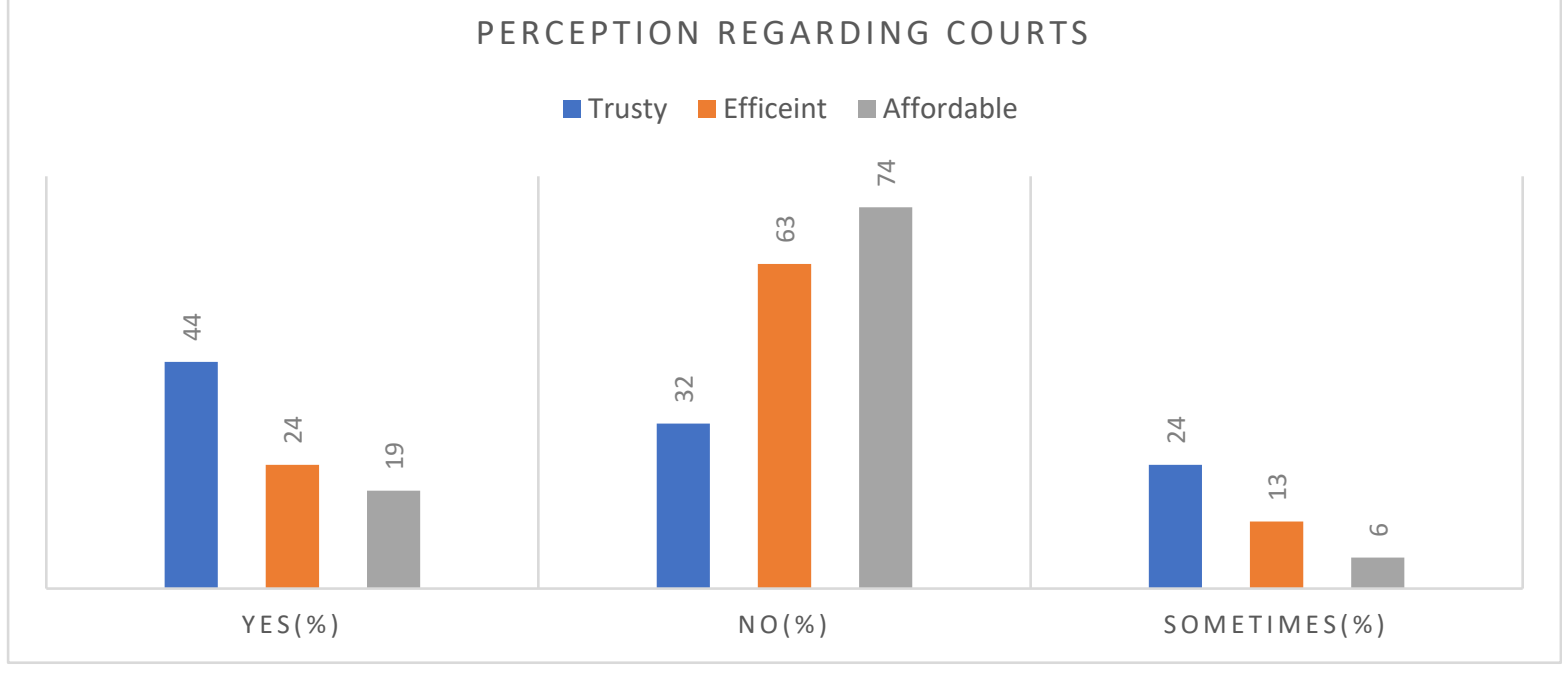


Figure 15: Respondent types reporting that they find police fair/trustworthy, affordable and speedy

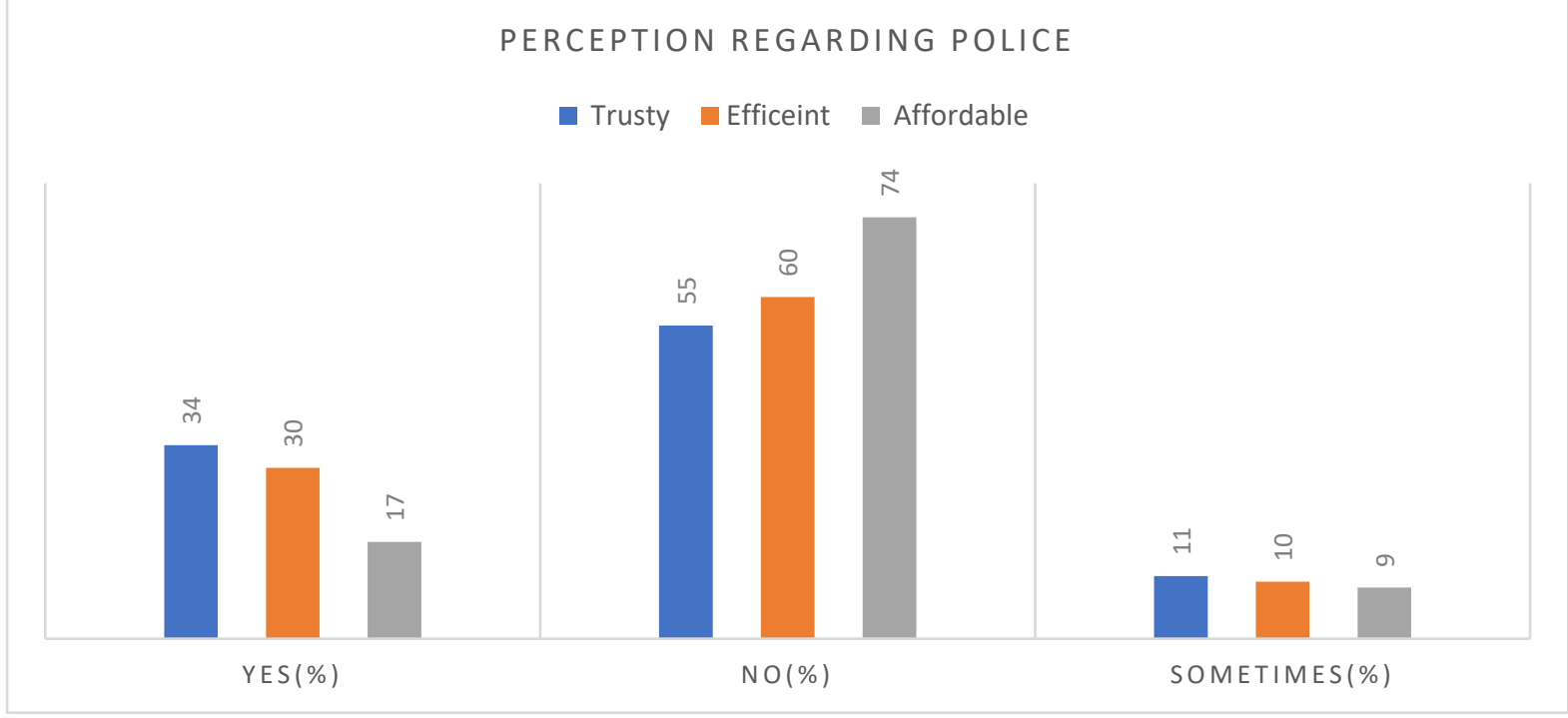

\section{Conclusion}

Institutional theory, as are of the standard approaches in the social science is an attempt to understand process of governance. Even in the states with a strong civil society organizations and networks, the formal institutions of governance remain important. The academic questions about the sort of theory all relevant for understanding and explaining the role of governance. In swat, disputes are taken up by both formal state institutions as well as informal ones. This research discussed the functioning and interaction of these different dispute resolution mechanisms. This study aims to describe the different attitudes of people towards formal and informal institutions. On the other hand, it aimed to provide a concise impression of the everyday functioning of these institutions with a view to facilitating legal empowerment initiatives. Keeping in mind that this research is a case study of provision of governance and justice delivery facilities in the North-West of Pakistan, it is worthwhile to consider the meanings of these findings and conclusions in a larger perspective. Even recent governance reform analyses like the "drivers of change" thesis conclude that informal institutions and culture are inert and formidable obstacle to good governance (Brown et al. 2006).

\section{References}

Ahmad, A. S. (1980), Millennium and Charisma Among Pathans: A Critical Essay in Social Anthropology. Routledge \& Routledge Paul.

Ahmad, J. \& Wangenheim, G. V. (2021). Access to justice: An evaluation of the informal justice systems. Liberal Arts and Social Sciences International Journal (LASSIJ), 5(1), 228-244. https://doi.org/10.47264/idea.lassij/5.1.16

Ahmad, N., Bano, A., \& Rehman, A. U. (2017). Impact of the informal institutional forces on the local government elections in Khyber Pakhtunkhwa, Pakistan. Liberal Arts and Social Sciences International Journal (LASSIJ), 1(1), 62-70. https://doi.org/10.47264/idea.lassij/1.1.7

Alam, F., Ahmad, S., \& Bano, A. (2020). Jirga and Dispensation of Social Welfare Services: A Case Study of Mohmand Tribal District, Pakistan. Liberal Arts and Social Sciences 
$\begin{aligned} & \text { International Journal } \\ & \text { https://doi.org/10.47264/idea.lassij/4.1.20 }\end{aligned}$
W., Mehmood, W. \& Hussain, S. (2018). Swat Conflict in Retrospect: Violence and Jarga among the Swat Pukhtuns in Pakistan. Liberal Arts and Social Sciences International Journal (LASSIJ), $\quad 2(1), \quad 37-48$. https://doi.org/10.47264/idea.lassij/2.1.5

Barth, F. (1998). Ethnic groups and boundaries: The social organization of culture difference. Waveland.

Bakker, P. (2009, May 25) Indigenous Family Law in South Africa: From Colonial Repugnancy to Association. Grand Hyatt, Denver, Colorado.

Collier, P., Hoeffler, A., \& Söderbom, M. (2008). Post-conflict risks. Journal of Peace Research, 461-478. https://journals.sagepub.com/doi/abs/10.1177/0022343308091356

Englebert, P. (2000). Pre-colonial institutions, post-colonial states, and economic development in tropical Africa. Political Research Quarterly, 53(1), 7-36. https://journals.sagepub.com/doi/abs/10.1177/106591290005300101

Haroon, S. (2011). Frontier of Faith: A History of Religious Mobilisation in the Pakistan Tribal Areas C. 1890-1950. Oxford University.

Harper, E. (2011a). Customary justice: From program design to impact evaluation. International Development Law Organization, Rome. https://www.files.ethz.ch/isn/138082/CustomaryJustice1.pdf

Harper, E. (2011b). Working with Customary Justice Systems: Post-Conflict and Fragile States. Rome, Italy: International Development Law Organization. https://www.files.ethz.ch/isn/138115/CustomaryJustice2.pdf

Hopkins, B., \& Marsden, M. (2013). Beyond Swat. Hurst and Company.

Huyse, L., \& Salter, M. (2008). Tradition-based Justice and Reconciliation After Violent Conflict. Learning from African Experiences. Stockholm: International IDEA. https://www.idea.int/sites/default/files/publications/traditional-justice-andreconciliation-after-violent-conflict-learning-from-african-experiences_0.pdf

Isser, D. (Ed.). (2011). Customary justice and the rule of law in war-torn societies. US Institute of Peace.

Isser, D., Lubkemann, S. C., Saah Charles, N. T., Addison, A., Ndebe, J., Saye, G., ... \& Sandefur, J. (2009). Looking for justice: Liberian experiences with and perceptions of local justice options. US Institute of Peace. https://www.usip.org/sites/default/files/liberian_justice_pw63.pdf

Khattak, A. H., Khattak, K. U., \& Zaheer, S. H. (2017). Security Issues in Pakistan: Its Solution in the light of Seerah. Liberal Arts and Social Sciences International Journal (LASSIJ), 1(2), 34-42. https://doi.org/10.47264/idea.lassij/1.2.4

Kötter, Matthias, Tilmann J. Röder, FolkeSchuppert, and RüdigerWolfrum, (2015) eds. NonState Justice Institutions and the Law: Decision-Making at the Interface of Tradition, Religion and the State. Palgrave Macmillan. https://lawandreligionforum.org/2015/01/09/

Lindholm, C. (1982). Generosity and jealousy: The Swat Pukhtun of northern Pakistan. Columbia University.

Mahmood, A., Ullah, S. \& Ashfaq, S. (2018). The Evolution of Jirga System: A Conflict Resolution Mechanism in FATA. Liberal Arts and Social Sciences International Journal (LASSIJ), 2(1), 21-28. https://doi.org/10.47264/idea.lassij/2.1.3 
Rome, S. I. (2008). Swat State (1915-1969) from genesis to merger: An analysis of political, administrative, socio-political, and economic developments. Oxford University.

Spain, J. W. (1972). The way of the Pathans. Oxford University.

Spain, James (1985), The Pathan Borderland. Oxford University.

Spain, James W. (2009). Pathans of the Later Day. Oxford University.

Sultan-i-Rome, S. A. (2009). Critical Analysis. Institute of Peace and Conflict Studies, 10. https://journals.sagepub.com/doi/abs/10.1177/2633002421994818

Taizi, S. (2007). Jirga system in tribal life. Area Study Center (Russia, China and Central Asia). University of Peshawar. https://www.tribalanalysiscenter.com/PDFTAC/Jirga\%20System\%20in\%20Tribal\%20Life.pdf

United Nations Development Program (2009). Conflict Early Recovery Initial Needs Assessment (CERINA) - Addressing the Governance Challenges in NWFP and FATA. http://pu.edu.pk/images/journal/pols/pdf-files/8_24_2_17.pdf

United Nations Development Program. (2011). Assessing Rule of Law, Peace \& Security in Malakand, NWFP. UNDP Archives. https://www.jstor.org/stable/resrep30844

Wojkowska, E. (2007). Doing Justice: How informal justice systems can contribute. https://www.un.org/ruleoflaw/files/UNDP\%20DoingJusticeEwaWojkowska130307. $\underline{\mathrm{pdf}}$

Won, S. K. (2013). Overview of alternate dispute resolution with special reference to arbitration laws in Pakistan. J. Arb. Stud., 23, 149. https://heinonline.org/HOL/LandingPage?handle=hein.journals/jarbstu23\&div=27\& id $=$ \&page $=$

Yousufzai, H. M., \& Gohar, A. (2005). Towards Understanding Pukhtoon Jirga: An indigenous way of peace building and more. Just Peace International. 


\section{Notes:}

${ }^{1}$ The Local Government Ordinance 2001 introduced a masalihati Jirga (reconciliatory committee) for dispute settlement at Union Council level.

${ }^{2}$ Frontier Crimes Regulation, implemented by the British Colonial power in 1901 in FATA and present Khyber Pakhtunkhwa.

${ }^{3}$ Panchayat in India and Punjab (Pakistan), Agora in ancient Greek, in Rome comitia curiata, shura in Arab tribal community, simte and sabha in the ancient Aryan tribes, are some of the historical institutions used for consultations and settling community matters. (Taizi, 2007: 2), also Fambul Tok (community talk) in Sierra Leon. In the modern world, a pre-trial settlement is in practice in the United States.

${ }^{4}$ Police and the courts for example.

${ }^{5}$ Culture and tradition in Pukhtun society are mostly based on orality. British Conventions can be compared with Pukhtun code of life.

${ }^{6}$ Taliban also used Jirga for resolving people's disputes in a short span of time and were successful in getting local support.

7 The UN estimates that in around $80 \%$ of disputes in many states in the world are resolved through informal justice mechanisms including traditional, indigenous, customary, or non-state systems (UN Rule of Law website, accessed 11 January 2015).

${ }^{8}$ CEDAW is the 1979 Convention on the Elimination of All Forms of Discrimination against Women. It is an apt example of the substantive human rights concerns customary justice systems are now expected to address.

9 The term of "justice vacuum" was coined by Lubkemann et al. (2010) to mean areas where justice reform interventions have not only failed to improve justice and accountability but have resulted in declining access. In 2011, almost the same group of scholars note that vacuum is "a place in which the powerful, wealthy, and socially connected are able to secure unfair advantages in dispute resolution — often through the formal court (Lubkemann et al., 2011, 100). An example of state restrictions without an alternative accessible mechanism leading to justice vacuum is the blanket prohibition on the use of trial by ordeal (TBO), also known as Sassywood in Liberia. While the UN and human rights groups hail the enforcement of this prohibition as triumph for human rights, Isser et al. found that Liberians blame the ban for a litany of problems including: depriving them of a reliable and effective tool for investigating crime and keeping local order as well as leading to a drastic increase in what is considered the most pernicious problems of witchcraft (Isser et al., 2009; Lubkemann et al., 2011).

${ }^{10}$ Only a handful of studies have begun exploring the role of customary justice systems in building the rule of law in war-torn societies (Harper 2011; Park 2008).

${ }^{11}$ For example, traditional justice systems are usually portrayed as restorative geared toward restoring social harmony, social interests, and victims' condition.

12 The definition provided to survey enumerators for the purposes of identifying respondents who would be considered JPs was as follows: "AJustice Provider is someone who resolves disputes in their community, outside their own household. They could do this within their extended family (comprising multiple households), within their village (e.g., as a jirga member or imam, or member of a musalihati committee), or outside their village (e.g., as a court official or police officer)." (Survey Protocols)

13 This might be due to increased support for Islamic, Shari'ah-based norms which state that, generally, one third of the inheritance should go to a female heir. On how the increased adoption of Islamic law is thus actually improving women's rights (to a certain extent), see Nelson, In the Shadow of Shari'ah. 